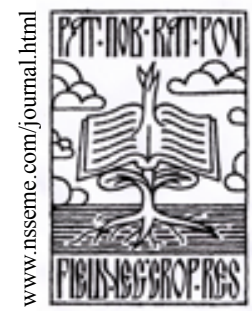

\title{
Legume Improvement Program at AVRDC -The World Vegetable Center: Impact and Future Prospects
}

\author{
Ramakrishnan Nair • Roland Schafleitner • Warwick Easdown • Andreas Ebert • Peter \\ Hanson • Jacqueline d'Arros Hughes • John Donough Heber Keatinge
}

\author{
received: 11 February 2014, accepted: 25 March 2014 \\ published online: 10 June 2014 \\ (C) 2014 IFVC \\ doi:10.5937/ratpov51-5488
}

\begin{abstract}
Summary: Legume breeding at AVRDC - The World Vegetable Center currently focuses on two crops: mungbean (Vigna radiata [L.] Wilzcek var. radiata) and vegetable soybean (Glycine max [L.] Merrill). High yielding, short duration mungbean varieties bred by AVRDC in conjunction with 29 national partners across Asia revolutionized the industry over the last two decades and increased global production by more than a third. New sources of resistance to mungbean yellow mosaic disease have been identified in related species such as black gram (Vigna mungo [L.] Hepper) and are being introgressed into elite mungbean lines. Improving protein quality by transferring high methionine and bruchid resistance traits from black gram is in progress. Selection of local land races and transfer of desirable traits from grain soybean are being used to develop vegetable soybean with higher pod yield, improved seed size and colour, higher sugar content, basmati flavour, less sensitive to photoperiod and temperature.
\end{abstract}

Key words: Asia, breeding, impact, legumes, mungbeans, vegetable soybeans, vigna

\section{Introduction}

Globally, the need for legume improvement programs was recognised during the 1970s not only for tackling protein malnutrition (FAO 1985), but also to include legumes as part of cropping systems. This was in the aftermath of cereal focused agricultural research, which began to show signs of environmental problems (ESCAP 1985, Evenson \& Gollin 2003, Sekhon et al. 2007). The legume program at AVRDC The World Vegetable Center has emphasized improvement of both mungbean (Vigna radiata [L.] Wilzcek var. radiata) and vegetable soybean (Glycine max [L.] Merrill) as its mandate crops.

Mungbean is one of the most important legume crops in Asia and is gaining popularity in other

R. Nair* $\bullet$ W. Easdown

AVRDC - The World Vegetable Center, South Asia, ICRISAT Campus, 502324 Hyderabad, AP, India

e-mail: ramakrishnan.nair@worldveg.org

R. Schafleitner • A. Ebert • P. Hanson • J. d'Arros Hughes • J.D.H. Keatinge

AVRDC - The World Vegetable Center, PO Box 42, Shanhua, Tainan 74151, Taiwan continents. Currently, mungbean is cultivated on more than 6 million hectares worldwide and global annual production is 3 million tonnes (Nair et al. 2013b). India has the greatest mungbean production followed by China and Myanmar (Fig. 1). It is consumed as processed dry grains (boiled dry seeds or split seeds as dhal (porridge) or made into noodles; the sprouts and green pods are eaten as vegetables. In addition to its easily digestible protein, mungbean provides essential micronutrients such as iron and zinc.

Vegetablesoybean, popularlyknownasedamame in Japan, maodou in China and green soybean in North America, is currently grown on more than 300,000 ha globally, with an annual production of 1.8 million tonnes (Shanmugasundaram et al. forthcoming). China accounts for more than $90 \%$ of the area and production of vegetable soybean. Vegetable soybean is a type of soybean from which the immature pod is harvested and used as a fresh or frozen vegetable. Immature pods are boiled and the seeds are extracted as a highly nutritious snack food. Vegetable soybean seeds are larger

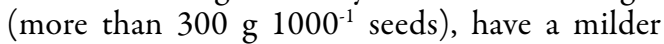
flavour, nuttier texture and are easier to cook in comparison to grain soybean. Nutritionally, 


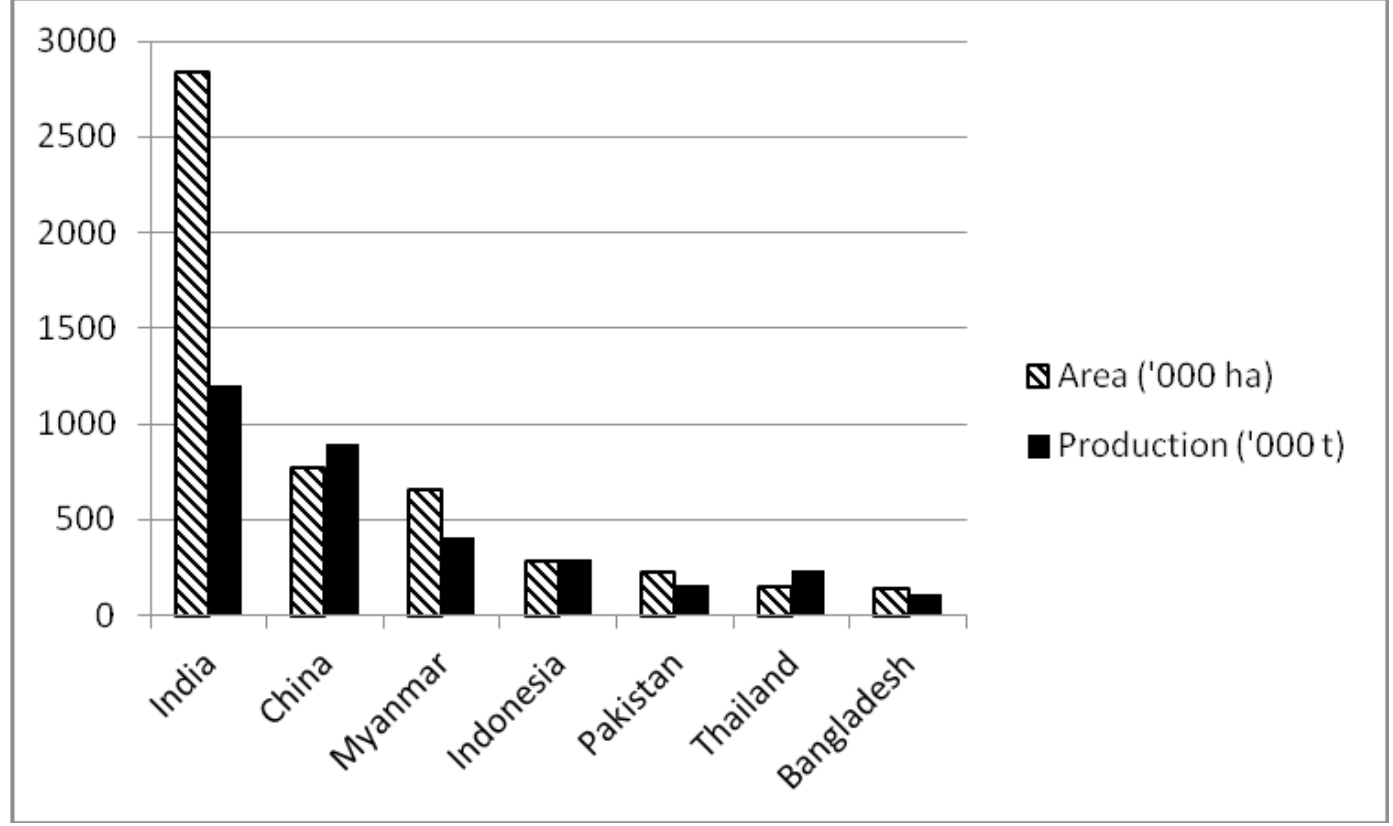

Figure 1. Area and production of major mungbean producing countries Latest available year - source: Bangladesh: Bangladesh Department of Agricultural Extension (2012); China: Mogotsi (2006); India: IIPR (2011); Indonesia: BPS-Statistics Indonesia, RIDS (2011); Myanmar: Weinberger (2003); Pakistan: Ali et al., (2010); Thailand: Chaitieng (2002). Downloaded from www.riceindonesia.com, accessed 24 April 2012.

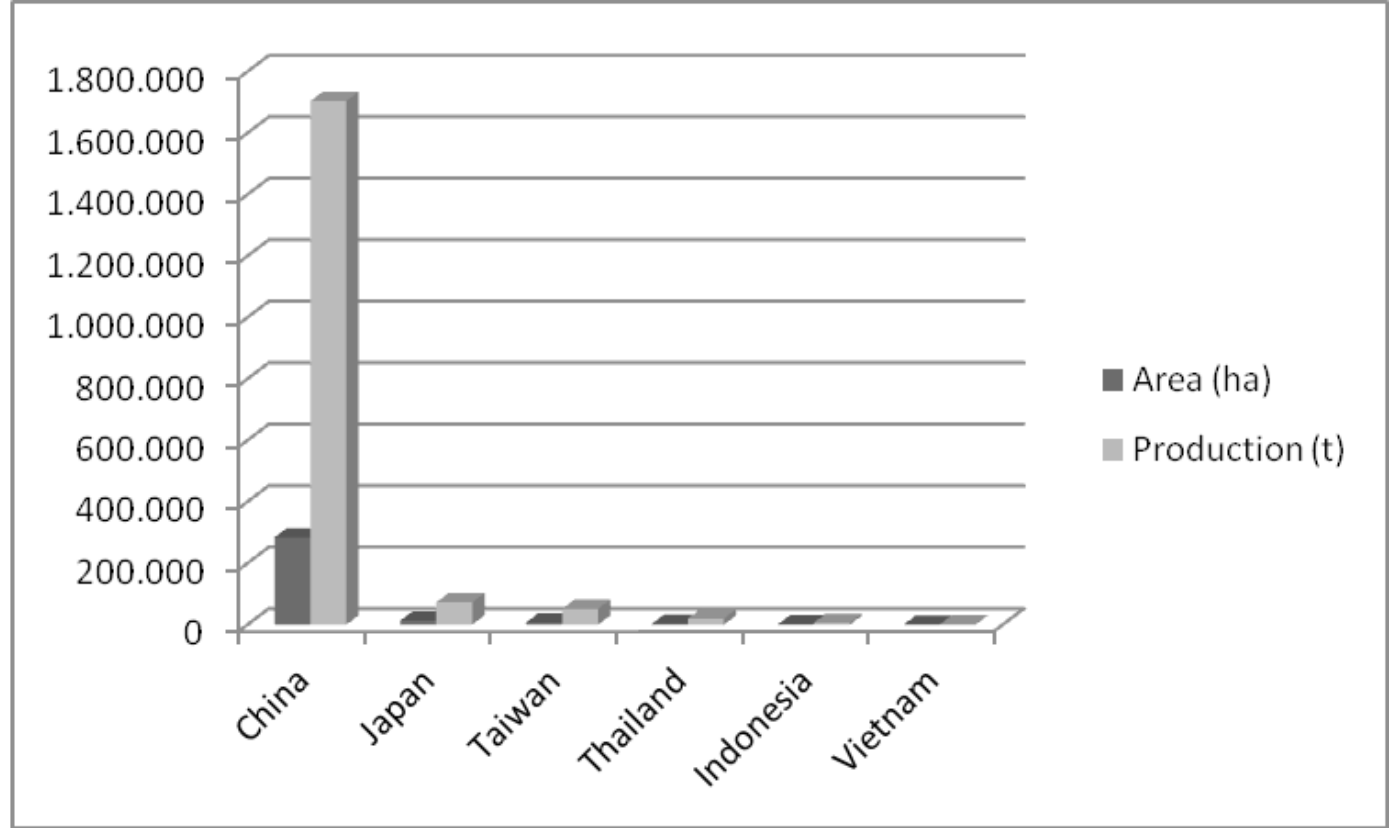

Figure 2. Area and production of major vegetable soybean producing countries (Source: Shanmugasundaram et al., forthcoming, data from various sources 2003-2010). 
vegetable soybean is rich in protein (13\%, fresh weight basis), cholesterol-free fat (5.7\%), phosphorus $\left(1.58 \mathrm{~g} \mathrm{~kg}^{-1}\right)$, calcium $\left(0.78 \mathrm{~g} \mathrm{~kg}^{-1}\right)$, vitamin $B_{1}\left(0.004 \mathrm{~g} \mathrm{~kg}^{-1}\right)$ and $B_{2}\left(0.0017 \mathrm{~g} \mathrm{~kg}^{-1}\right)$. Seeds also contain isoflavones and tocopherol (Shanmugasundaram \& Yan 1999). The trypsin inhibitor activity in vegetable soybean is lower than in grain soybean.

China, Japan, Taiwan, Thailand, Indonesia and Vietnam are the major vegetable soybean producing countries (Fig. 2). The average productivity of vegetable soybean cultivated during the spring and summer seasons in China ranges from 4.5 to $6.0 \mathrm{tha}^{-1}$, and 6.0 to $7.5 \mathrm{tha}^{-1}$, respectively (Tsay et al. 1991). Prior to 1975 , the total area and production of vegetable soybean in Taiwan was negligible, but both increased from 6,500 ha and 40,000 t in 1980 to nearly 10,000 ha and around $65,000 \mathrm{t}$ by 1990 , respectively (Cheng 1991, Lin \& Cheng 2001). However, due to the increasing value of land and high cost of labour, vegetable soybean production slowly decreased from 1999 in Taiwan and its share of global production was taken over by China, Thailand and Indonesia, where production costs are lower. The majority of the vegetable soybean produced is exported to Japan.

This review covers the impact of AVRDC's mungbean and vegetable soybean research.

\section{Impact through Mungbean Improvement}

Over the past two decades, in collaboration with 29 national partners in Asia, AVRDC has made significant improvements in mungbean production and productivity through a wellcoordinated, multidisciplinary approach. One key step was the establishment the South Asia Vegetable Research Network (SAVERNET), consisting of national partners from six participating countries. Another key activity was the assembly and utilization of the world's largest collection of Vigna germplasm at AVRDC. Defining an ideal mungbean ideotype for Asia, combining traits from lines from the Philippines and India, shuttle breeding between AVRDC and national partners, particularly from Pakistan, and testing of lines in international mungbean nurseries were some highlights of this cooperative effort (Shanmugasundaram et al. 2009). Varieties developed included lines with shorter duration (55-70 days to maturity compared to the traditional ones that matured in 90-110 days); resistance to major diseases such as mungbean yellow mosaic, Cercospora leaf spot and powdery mildew; lines that were less photoperiod sensitive and had synchronized maturity; improved plant habit such as plant types with pods above the canopy; and improved tolerance to lodging and pod shattering. The adoption of these varieties led to a substantial increase in production and productivity, particularly in South and Southeast Asia. The impact was evident where mungbean was grown in crop rotation. The shorter maturity period of the crop made it a perfect fit into cereal based cropping systems, such as rice-wheatmungbean and rice-potato-mungbean practiced in Asia. Mungbean interventions were focused in Bangladesh, Bhutan, China, India, Nepal, Myanmar, Pakistan, Sri Lanka and Thailand. The Department for International Development (DFID), United Kingdom supported the promotion of research outputs for adoption by farmers in South Asia. This helped with multiplication of seed of elite lines through establishment of a seed village concept (Bains et al. 2006), wherein farmers produced their own seed.

The impact made by interventions with mungbean can be categorized mainly into enhanced production, sustaining soil productivity, health and nutritional benefits, economic benefits and capacity building (Shanmugasundaram et al. 2009).

The adoption of improved varieties by farmers in Punjab, Pakistan resulted in 55\% higher yields compared to local varieties. Moreover, there were savings (23\%) in the production cost by adopting mungbean as part of a crop rotation with wheat (Ali et al. 1997). Adopters of improved mungbean varieties in Bangladesh increased their average yields by $40 \%$ with an estimated benefit-cost ratio of 2.18, compared to non-adopters (Afzal et al., 2006). In China, the efforts of AVRDC led to the recovery of mungbean production; the production level increased from 500,000 $t$ in 1986 to $891,000 \mathrm{t}$ in 2000 , and productivity increased from $914 \mathrm{~kg} \mathrm{ha}^{-1}$ to $1154 \mathrm{~kg} \mathrm{ha}^{-1}$ during the same period. Consumption rose as well; the share of mungbean in total pulse consumption increased from $14.2 \%$ (1986) to $28.0 \%$ (2000) (Huijie et al. 2003).

Inclusion of shorter duration mungbean varieties such as 'SML 668' after the wheat crop in Punjab, India showed that the residual nitrogen could meet $25 \%$ of the $\mathrm{N}$ requirement of the following rice crop (Sekhon et al., 2007).

The national economic impact of enhanced iron intake due to mungbean consumption and its effect on the productivity of anemic female workers in Pakistan were studied by Weinberger (2003), who found that the economic benefit 
to the country was US \$3.51-4.21 million in additional annual income, primarily from women whose health improved as a result of increased mungbean consumption through the adoption of improved varieties.

In China, mungbean imports dropped significantly from a value of $\$ 13.6$ million (1986) to $\$ 1.4$ million (2000) and at the same time the exports increased from $\$ 45$ to $\$ 50$ million. Farmers in Punjab, India earned about US \$500$700 \mathrm{ha}^{-1}$ by growing shorter duration mungbean varieties; the net returns over variable costs in rice-wheat-mungbean production systems were US \$200 higher than in rice-wheat systems (Sekhon et al. 2007).

Capacitybuildingwasachieved in countriessuch as India and Bangladesh through development of 'seed villages' in which farmers produced their own seed; this fostered greater expansion of the crop (Shanmugasundaram et al. 2009).

\section{Impact through Vegetable Soybean}

AVRDC began vegetable soybean research in 1976 and in 1981 the Kaohsiung District Agricultural Research and Extension Station (DARES) joined forces with AVRDC in developing improved vegetable soybean cultivars for Taiwan, specifically for export to Japan. The Council of Agriculture and the Provincial Department of Agriculture and Forestry, Taiwan supported the vegetable soybean research at AVRDC for nearly 20 years, working in collaboration with the Kaohsiung and Tainan DARES (Shanmugasundaram et al. forthcoming). The Center's genebank houses 15,321 Glycine accessions and vegetable soybean types account for about $15 \%$ of the G. max collection. More than 3,000 breeding lines have been distributed to researchers worldwide, including those that are less sensitive to photoperiod and temperature to extend adaptability to tropical zones. Selections from local landraces and transfer of desirable traits from grain soybean have been employed in the breeding program.

AVRDC has played a pivotal role in promoting awareness about the crop in different parts of the world. Through the efforts of AVRDC's regional operations in Africa, many African countries including Zimbabwe, Mauritius, Uganda, Tanzania, Sudan, Zambia, Mozambique and South Africa are beginning vegetable soybean production, processing, marketing and consumption (Chadha \& Oluoch 2004). AVRDC South Asia in Hyderabad, India introduced GC89009-1-1-2, which was released in 2008 as 'Swarna Vasundhara' by the Central Variety Release Committee (CVRC) of the Government of India (Pan et al. 2007). A total of $1.4 \mathrm{t}$ of seeds of the new variety were produced for distribution to farmers during 2012.

With the research conducted by AVRDC's regional scientists in Central Asia and the Caucasus vegetable soybean is gaining entry into Azerbaijan, Kazakhstan and Uzbekistan. Since 2005, AVRDC has distributed vegetable soybean germplasm to the region and several lines were developed by the Kazakh Research Institute for Potato and Vegetable Cultivation, the Uzbek Research Institute of Plant Industry, the Research Institute for Horticulture and Vegetable Cultivation in Tajikistan and the Research Institute for Crop Husbandry in Georgia. Six varieties were released, including four early-maturing and two mid-maturing varieties. Early maturing lines can be harvested 60 days after sowing and mid-maturing varieties, 90 days after sowing. The mid-maturing varieties produced higher green pod and seed yields $(20 \mathrm{t}$ $\mathrm{ha}^{-1}$ and 7.5-8 tha $\mathrm{t}^{-1}$, respectively) than the earlymaturing varieties $\left(9-11 \mathrm{t} \mathrm{ha}^{-1}\right.$ and 3.5-4 $\mathrm{tha}^{-1}$, respectively) (AVRDC, 2013). Early-maturing varieties 'Ilkhom' and 'Universal' recorded good yields even at an altitude of $880 \mathrm{~m}$ in the Piedmont area of Bostanlyk, Uzbekistan. In Uzbekistan, vegetable soybean was planted on 30 ha in 2011 (Ravza Mavlyanova, personal communication).

A number of states in the US are currently producing and marketing vegetable soybean, and recently Arkansas was designated as the 'Edamame Capital of the USA'. It is estimated that the current area under vegetable soybean in the USA is around 2,000 ha (Cartright \& Medders 2012).

\section{Future Prospects for Mungbean}

The growing popularity of mungbean has led to an expansion of the global area cultivated to more than 6 million hectares (Nair et al. 2012). An international pedigree management system recently has been developed to help breeders select parents and avoid duplication. Broadening the genetic base of mungbean is a priority and breeding programs increasingly use crosses between unrelated parents and inter-specific hybridization. This is important to tackle problems such as mungbean yellow mosaic disease, for which currently available sources of resistance are insufficient to cope 
with disease pressure in certain locations. Black gram (Vigna mungo (L.) Hepper) is being used as a source of resistance to mungbean yellow mosaic disease, as well as for improving protein quality (high methionine) and bruchid resistance. A mungbean core collection comprising 1,490 accessions representing the diversity of the entire AVRDC - The World Vegetable Center mungbean collection has been established and facilitates access to diverse parental material for breeders. Current marker systems for mungbean are insufficient to sustain molecular breeding because of the crop's narrow genetic base, which results in reduced genetic diversity and a low polymorphism rate of markers. Single nucleotide polymorphism (SNP) markers are abundant in the genome and could provide an appropriate resource for molecular breeding. Restriction enzymerelated DNA (RAD) sequencing experiments has generated thousands of SNP markers for important mungbean breeding populations. This will enable fine mapping of simple and complex traits and assist in backcrossing and recurrent selection for faster breeding progress. Draft whole genome sequences for mungbean and some wild relatives will become available at the beginning of 2014 and will strengthen genomics research and molecular breeding of this crop. The broad availability of genomic resources will make mungbean a model legume crop and will facilitate genomics and proteomics approaches, leading to the identification of key genes conferring improved agronomic performance and nutritional quality. Reviving international mungbean screening network will help expand sharing of improved lines between different countries. Access to good quality seed of improved varieties coupled with the adoption of improved agronomic practices are critical for improving productivity.

\section{Future Prospects for Vegetable Soybean}

A concerted effort backed by national partners, farmer organizations and the private sector is needed to promote the crop in South Asia and sub-Saharan Africa. As a part of its ongoing work, AVRDC is testing new lines of vegetable soybean in multi-location trials in different countries, with a wide range of seed colours and qualities. These include lines with basmati rice flavour-a popular taste that commands a high price premium. To enhance the taste of vegetable soybean, breeders have successfully utilized fragrance (2-acetyl -1-pyrroline content) genes from the Japanese cultivars 'Dadachamame' and 'Chakaori' to develop vegetable soybean lines with a basmati rice flavour. Molecular markers for the fragrance trait have been developed (Juwattanasomranet al. 2010), which will facilitate the selection for this trait in breeding programs. Basmati-flavoured lines may help to hasten the acceptability of the crop particularly in the Indian sub-continent. Consumer acceptance is vital to the success of a new crop. Promoting vegetable soybean recipes designed to suit local tastes would help gain wider acceptance of the crop. This has been successfully accomplished in the state of Jharkhand in India, where tribal communities have started to consume vegetable soybean as a substitute for garden pea (Pisum sativum) and also have developed their own recipes.

One of the major challenges in promotion of a new crop is to provide sufficient quantities of seed of improved cultivars to farmers. In India, vegetable soybean cultivar 'Swarna Vasundhra' has been the mainstay of the crop's expansion in India to date. Thanks to the efforts of an AVRDC - Sir Ratan Tata Trust project, seed of this cultivar has been produced by more than 300 farmers in the state of Jharkhand and is helping to meet local demand for seed. The main need now is to increase vegetable soybean production to a level beyond that which can be absorbed by local markets, and to promote it in other parts of India to create a strong and permanent demand for this new crop (Nair et al. 2013a). In addition, we have been working with lead farmers in grain soybean growing states like Maharashtra to produce good quality seed, as well as to promote the benefits of the crop.

Further expansion of the crop into new regions (Keatinge et al. 2011) will require creating greater awareness about the nutritive value of vegetable soybean, increasing the supply of good quality seed, and monitoring the occurrence of major pests and diseases in new locations. 


\section{Conclusions}

The availability, affordability and acceptability of foods essential to a balanced diet, including legumes, are important for good health. To improve mungbean productivity, the genetic base of the crop needs to be broadened by using parents from different backgrounds including inter-specific hybridization. Improvement of vegetable soybean with higher pod yield, improved seed size and colour, higher sugar content and basmati flavour includes the use of selections from local landraces and the transfer of desirable traits from grain soybean. Further expansion of the mungbean area under cultivation, promoting the nutritional qualities of mungbean and vegetable soybean, ensuring sustainable supplies of vegetable soybean seed to willing farmers, and public-private-farmer partnerships in the vegetable soybean industry will take us forward in addressing the problems of human malnutrition.

\section{References}

Afzal, M.A., Bakr, M.A., Hamid, A., Haque, M.M., \& Aktar, M.S. (2006). Adoption and seed production mechanisms of modern varieties of mungbean in Bangladesh. In: Improving income and nutrition by incorporating mungbean in cereal fallows in the Indo-Gangetic Plains of South Asia, DFID Mungbean Project for 2002-2004. AVRDC Publication No. 06-682. Shanhua, Taiwan: The World Vegetable Center (AVRDC)

Ali, M.A., Abbas, G., Mohy-ud-Din, Q., Ullah, K., Abbas, G., \& Aslam, M. (2010). Response of mungbean (Vigna radiata) to phosphatic fertilizer under arid climate The Journal of Animal \& Plant Sciences, 20: 83-86.

Ali, M., Malik, I.A., Sabir, H.M., \& Ahmad, B. (1997). The mungbean green revolution in Pakistan. Asian Vegetable Research and Development Center, Shanhua, Taiwan, Technical Bulletin No. 24.

AVRDC (2013). Vegetable soybean, a new crop with high potential for Central Asia and the Caucasus, FEEDBACK from the Field, AVRDC - The World Vegetable Center, Issue No.17, $1-3$.

Bangladesh Department of Agricultural Extension (2012). Agricultural Statistics http://www.dae.gov.bd/crop-statistics/pulse-crops/ Accessed Jan 102012

Bains, T.S., Brar, J.S., Singh, G., Sekhon, H.S., \& Kumar, B.S. (2006). Status of production and distribution of mungbean seed in different cropping systems. In: S Shanmugasundaram (ed.) Improving income and nutrition by incorporating mungbean in cereal fallows in the Indo-Gangetic Plains of South Asia. AVRDC Publication No. 06-682. Shanhua, Taiwan,The World Vegetable Center (AVRDC).

Cartright, K., \& Medders, H. (2012). Vegetable soybean company to make Mulberry 'edamame capital of US. (http://arkansasagnews.uark.edu/6583.htm) accessed Oct. 2012.

Chadha, M.L., \& Oluoch, M.O. (2004). Vegetable soybean research and development in Africa In: F Moscardi, C B Hoffmann-Campo, O F Saraiva, P R Galerani, F C Krzyzanowski, M C Carrão-Panizzi(eds.) Proc $7^{\text {th } W o r l d ~ S o y b e a n ~}$ Research Conference and $6^{\text {th }}$ International Soybean Proce- ssing and Utilization Conference. Foz do Iguassu, PR, Brazil, 921-928.

Chaitieng, B. (2002). Inheritance of powdery mildew resistance in mungbean and development of molecular markers for marker assisted selection. PhD Thesis Suranaree University of Technology, Nakhon Ratchasima, Thailand, $72 \mathrm{p}$.

Cheng, S.H. (1991). Vegetable soybean area, production, foreign and domestic trade in Taiwan. In: S Shanmugasundaram (ed.) Proc of Vegetable Soybean - Research Needs for Production and Quality Improvement Workshop. Asian Vegetable Research and Development Center, Shanhua, Tainan, Taiwan, $17-21$.

ESCAP (United Nations Economic and Social Commission for Asia and the Pacific) (1985). Economic and social survey of Asia and the Pacific. Bangkok, Thailand: ESCAP.

Evenson, R.E., \& Gollin, D. (2003): Assessing the impact of the green revolution, 1960 to 2000. Science, 300: 758-762.

FAO (Food and Agriculture Organization of the United Nations) (1985): The state of food and agriculture. Rome: FAO.

Huijie, Z., Li, N.H., Cheng, X.Z., \& Weinberger, K. (2003). The impact of mungbean research in China. AVRDC Publication No. 03-550, Working Paper No.14.Shanhua, Taiwan,The World Vegetable Center (AVRDC).

Indian Institute of Pulses Research (2011). ICAR, Indian Institute of Pulses Research, Vision 2030, Gupta S ed., Kanpur, 42 p.

Juwattanasomran, R., Somta, P., Kaga, A., Chankaew, S., Shimizu, T., Sorajjapinun, W., \& Srinives, P. (2010). Identification of a new fragrance allele in soybean and development of its functional marker. Mol Breed. 29:13-21.

Keatinge, J., Easdown, W., Yang, R., Chadha, M., \& Shanmugasundaram, S. (2011). Overcoming chronic malnutrition in a future warming world: the key importance of mungbean and vegetable soybean. Euphytica, 180, 129-141.

Lin, F.H., \& Cheng, S.T. (2001). Vegetable soybean development for export to Japan - A historical and technical perspective. In:

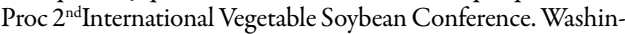
gton State University, Tacoma, Washington, USA, 87-91.

Mogotsi, K.K. (2006).Vignaradiata (L.) R.Wilczek. [Internet] Record from Protabase. M. Brink, and G. Belay, eds., PROTA (Plant Resources of Tropical Africa / Ressourcesvégétales de l'Afriquetropicale), Wageningen, Netherlands. < http://database.prota.org/search.htm>. Accessed 25 April 2012.

Nair, R.M., Ravishankar, M., Pan, R.S., Bhushan, B., Kaur, D.P., Ranchod, G.R., Yan, M-R., \& Easdown, W.E. (2013a). Vegetable soybean: a crop with immense potential for human nutrition. Fifth International Symposium on Human Health Effects of Fruits and Vegetables (FAV Health 2012), UAS Dharwad, 7-11 January 2013.

Nair, R.M., Yang, R.Y., Easdown, W. J., Thavarajah, D., Thavarajah, P., Hughes, J d'A., \& Keatinge, J.D.H. (2013b). Biofortification of mungbean (Vignaradiata) as a whole food to enhance human health. J Sci Food Agric.93, 1805-1813.

Nair, R.M., Schafleitner, R., Kenyon, L., Srinivasan, R., Easdown, W., Ebert, A., \& Hanson, P. (2012). Genetic improvement of mungbean SABRAO Journal of Breeding and Genetics 44 (2) $177-190$

Pan, R.S., Singh, A.K., Kumar, S., \& Rai, M. (2007). Stability of yield and its components in vegetable soybean (Glycine max) Indian J Agric Sci. 77: 28-31.

RIDS (2011): Downloaded from www.riceindonesia.com accessed 24April 2012,

Sekhon, H.S., Bains, T.S., Kooner, B.S., \& Sharma, P. (2007). Grow summer mungbean for improving crop sustainability, farm income, and malnutrition. Acta Hort.752: 459-464.

Shanmugsundaram, S., Keatinge, J.D.H., \& Hughes, Jd'A. (2009). The mungbean transformation, diversifying crops, defeating malnutrition. IFPRI Discussion Paper 00922 [Online]. Available:http://www.ifpri.org/millionsfed Accessed [24 April 2012]. 
Shanmugasundaram, S., Nair, R.M., Yan, M.R., \& Palada, MC. (2014). Vegetable soybean (Edamame) In: Handbook of Vegetables, Volume II, K V Peter and P Hazra (eds.). Forthcoming.

Shanmugasundaram, S., \& Yan, M.R. (1999). AVRDC vegetable soybeans for nutritional security, income generation and soil sustainability. ProcWSRC-VI, Chicago,USA, 4-7 August 1999 , pp. 450.
Tsay, J.S., Lai, S.H., \& Tsai, C.L. (1991). Present and potential cropping systems for soybean in Taiwan. In: Shanmugasundaram, S. (ed.) Proceedings of Vegetable Soybean - Research Needs for Production and Quality Improvement Workshop. Asian Vegetable Research and Development Center, Shanhua, Tainan, Taiwan, pp. 65-72.

Weinberger, K. (2003). Impact analysis of mungbean research in South and Southeast Asia. Final report of GTZ Project.The World Vegetable Center (AVRDC), Shanhua, Taiwan.

\title{
Program unapređenja mahunarki u AVRDC - Svetskom centru za povrtarstvo: Uticaj i budući razvoj
}

\author{
Ramakrishnan Nair • Roland Schafleitner • Warwick Easdown • Andreas Ebert • \\ Peter Hanson • Jacqueline d'Arros Hughes • John Donough Heber Keatinge
}

\begin{abstract}
Sažetak: Oplemenjivanje mahunarki u AVRDC - Svetskom centru za povrtarstvo se trenutno fokusira na dve biljne vrste: azijski pasulj (Vigna radiata [L.] Wilzcek var. radiata) i edamame zelenu soju (Glycine max [L.] Merrill). Azijski pasulj visokog prinosa i kratke vegetacije odgajan u Svetskom centru za povrtarstvo u saradnji sa 29 međunarodnih partnera širom Azije je revolucionisao industriju u poslednje dve decenije i povećao svetsku proizvodnju za više od $30 \%$. Novi izvori otpornosti na virus žutog mozaika azijskog pasulja su identifikovani u srodnim vrstama kao što je crna vigna (Vigna mungo [L.] Hepper) i introgresiraju se u elitne linije azijskog pasulja. U toku je poboljšanje kvaliteta proteina pomoću prenošenja osobina visoke otpornosti prema metioninu i pasuljevom žižku iz crne vigne. Selekcija lokalnih zemljišnih sojeva i prenos poželjnih osobina iz soje za zrno se koriste kako bi edamame zelena soja poboljšala prinos mahuna, veličinu zrna i boju, imala veći sadržaj šećera, basmati ukus i bila manje osetljiva na fotoperiod i temperature. Ključne reči: Azija, oplemenjivanje, uticaj, mahunarke, azijski pasulj, edamame zelena soja, vigna
\end{abstract}

